\title{
A non-occluded, systemic baculovirus that occurs in cells of ectodermal and mesodermal origin and causes high mortality in the black tiger prawn Penaeus monodon
}

\author{
Chainarong Wongteerasupaya ${ }^{1}$, Joan E. Vickers ${ }^{4}$, Siriporn Sriurairatana ${ }^{5}$, \\ Gary L. Nash ${ }^{6}$, Anutara Akarajamorn ${ }^{6}$, Vichai Boonsaeng ${ }^{1}$, Sakol Panyim ${ }^{1}$, \\ Anchalee Tassanakajon ${ }^{7}$, Boonsirm Withyachumnarnkul $^{2}$, T. W. Flegel ${ }^{3, *}$ \\ ${ }^{1}$ Dept Biochemistry, ${ }^{2}$ Dept Anatomy, ${ }^{3}$ Dept Biotechnology, Fac. Science, Mahidol University, Rama VI Road, \\ Bangkok 10400, Thailand \\ ${ }^{4}$ Dept Microbiology, University of Queensland, Brisbane 4072, Australia \\ ${ }^{5}$ Dept Pathology, Fac. Medicine, Ramathibodi Hospital, Mahidol University, Rama VI Road, Bangkok 10400, Thailand \\ ${ }^{6}$ Charoen Pokphand Shrimp Culture Research Center, 82/2 Thonburi-Paktor Road, Klong Sunakhon, M 4 Bangtorat, \\ Amphur Muang, Samut Sakorn, Thailand \\ ${ }^{7}$ Dept Biochemistry, Fac. Science, Chulalongkorn University, Phayathai Road, Bangkok 10330, Thailand
}

\begin{abstract}
In the course of experimental infection of Penaeus monodon with yellow-head virus (YHV) for virus isolation and purification, 1 batch of prawns yielded hemolymph fractions dominated by a previously undescribed non-occluded baculovirus rather than YHV. Injection of test shrimp with a semipurified preparation of this virus gave rapid mortality, and examination with the transmission electron microscope revealed a dual infection where cells containing the new virus dominated, but some cells containing YHV could also be seen. The tissues infected by the 2 viruses were similar. However, in contrast to YHV, the new virus was assembled completely in the nucleus and in the absence of occluding protein (polyhedrin). By normal histology, the most characteristic feature of infection was eosinophilic Cowdry A-type inclusions in hypertrophied nuclei with marginated chromatin, especially in epithelial cells of the stomach. These intranuclear inclusions became lightly basophilic in late stages of infection. In the epithelial cells of the gills, ultrastructural pathology included nuclear hypertrophy and cytoplasmic disintegration leading to large voids at lysed cell sites. By negative staining, completely assembled, enveloped virions were ellipsoid to obovate with a distinctive multifibrillar appendage and they measured $276 \times 121 \mathrm{~nm}$ (excluding the appendage). Enveloped and unenveloped nucleocapsids were significantly different un size, indicating possible shortening and thickening of the viral core and nucleocapsid during viral assembly. Isolation and punfication of the nucleic acid from the new virus yielded double-stranded DNA of approximately 168 kilo base pairs. This DNA did not cross-hybridize with DNA fragments isolated from YHV-infected shrimp or from monodon baculovirus (MBV). The features placed this virus in the family Baculoviridae, subfamily Nudibaculovirinae as PmNOBII, but for convenience we have named it informally as Systemic Ectodermal and Mesodermal Baculovirus (SEMBV).
\end{abstract}

KEY WORDS: PmNOBII - Nudibaculovirinae SEMBV - Shrimp $\cdot$ Black tiger prawn $\cdot$ Penaeus monodon

\section{INTRODUCTION}

In 1992 in Thailand, the pond harvest losses attributed to yellow-head virus (YHV) were estimated to be approximately 30 million US dollars (Anonymous 1993). As a result of the serious nature of the disease

- Addressee for correspondence the government of Thailand, through the National Center for Genetic Engineering and Biotechnology, set up a national task force of shrimp pathologists to coordinate and accelerate research activities aimed at limiting losses from the disease. One project included in the task force activities was to develop a specific DNA probe for YHV. In the plan for this project, YHV was to be amplified for isolation and purification using 
laboratory-reared shrimp Penaeus monodon by injection of a YHV viral extract. The original viral extract used for the study was derived from shrimp naturally infected with YHV. It consisted of membrane-filtered $(0.45 \mu \mathrm{M})$ gill homogenates in lobster hemolymph buffer. However, subsequent extracts (same methodology) were prepared from succeeding batches of laboratory shrimp used to maintain the virus by serial transfer at approximately 2 wk intervals

Three batches of shrimp were prepared in this way for YHV purification followed by nucleic acid extraction and characterization, without any unexpected difficulties occurring. However, during the purification process with the fourth batch of shrimp, a new and unexpected virus was found to dominate over YHV when negatively stained, partially purified viral extracts were examined by transmission electron microscopy. This study was carried out to partially characterize the new virus and test its virulence for Penaeus monodon.

\section{MATERIALS AND METHODS}

Primary virus isolation and purification. Juvenile shrimp Penaeus monodon were each injected intramuscularly with $0.1 \mathrm{ml}$ of a membrane-filtered $(0.45 \mu \mathrm{M})$ virus extract in lobster hemolymph buffer (LHB) (Boonyaratpalin et al. 1993). The extracts were derived from LHB gill homogenates of infected shrimp that were approximately in the 20th serial passage over $1.5 \mathrm{yr}$ from a natural yellow-head infection. This extract was believed to contain a high quantity of YHV and the purpose of the test was to attempt isolation and purification of YHV from hemolymph. At 48 h post-injection of the virus preparation, most of the shrimp were moribund. Hemolymph was collected from 200 shrimp by dripping from clipped (flame-sterilized scissors) telsons (wiped with $70 \%$ ethanol), and it was mixed with an equal volume of LHB on ice.

The pooled hemolymph was centrifuged at $5000 \mathrm{rpm}$ for $30 \mathrm{~min}$ at $4^{\circ} \mathrm{C}$. The supernatant was then ultracentrifuged at $100000 \times g$ at $4^{\circ} \mathrm{C}$ for $1 \mathrm{~h}$. The supernatant was discarded and the pellet was resuspended in $2 \mathrm{ml}$ of $\mathrm{NT}(0.2 \mathrm{M} \mathrm{NaCl}, 0.02 \mathrm{M}$ Tris- $\mathrm{HCl}, \mathrm{pH} 7.4)$ at $4^{\circ} \mathrm{C}$. This suspension was layered onto the top of a continuous gradient of $15 \%$ to $45 \%$ Urografin and ultracentrifuged at $100000 \times g$ on a Beckman ultracentrifuge (SW40 rotor) for $1.5 \mathrm{~h}$ at $4^{\circ} \mathrm{C}$. After centrifugation, viral bands were visualized by top illumination and were removed using a Pasteur pipette. A drop of each fraction was used for negative staining and visualization with the transmission electron microscope (see below). The remainder of the removed bands were diluted with an equal volume of NTE buffer
(0.2 M NaCl, 0.02 M Tris- $\mathrm{HCl}$ and $0.02 \mathrm{M} \mathrm{EDTA})$ at $\mathrm{pH}$ 7.4 and centrifuged at $100000 \times g$ for $1 \mathrm{~h}$. The pellet was then resuspended in $3 \mathrm{ml}$ of TE buffer $110 \mathrm{mM}$ Tris- $\mathrm{HCl}$ and $1 \mathrm{mM}$ EDTA) at $\mathrm{pH} 8$ and stored at $-70^{\circ} \mathrm{C}$ until used.

For transmission electron microscopy (TEM), negatively stained samples were prepared on formvar coated copper grids as follows. A small drop of sample was placed on the grid and left to stand for $3 \mathrm{~min}$ before excess fluid was withdrawn with a piece of tissue paper held to the side of the grid. Then a drop of $0.5 \%$ sodium phosphotungstate (Sigma Chemical Co. St. Louis, MO, USA) was placed on the grid and left for 2 min before the excess was removed as above. After air drying, the grids were examined with a Hitachi HU-12A transmission electron microscope.

Nucleic acid isolation and characterization. Stored fractions in TE (above) confirmed by TEM to contain large amounts of viral material were transferred to $1.5 \mathrm{ml}$ polypropylene centrifuge tubes. Triton X-100 was added to a final concentration of $0.02 \%$ and the tube incubated at room temperature for $10 \mathrm{~min}$ to remove viral envelopes. Proteinase-K and EDTA were added to give final concentrations of $100 \mu \mathrm{g} \mathrm{ml}^{-1}$ and $5 \mathrm{mM}$, respectively. After digestion at $65^{\circ} \mathrm{C}$ for $1 \mathrm{~h}$, $0.05 \mathrm{ml}$ of $10 \%$ sarkosyl was added and incubation was continued at $65^{\circ} \mathrm{C}$ for an additional $1 \mathrm{~h}$. Finally the DNA was extracted with phenol:chloroform: isoamyl alcohol $(25: 24: 1)$, precipitated with ethanol and dissolved in TE buffer containing RNase at a final concentration of $20 \mu \mathrm{g} \mathrm{ml} 1$.

Viral DNA was digested with either EcoRI or BamHI, and then electrophoresed in $0.8 \%$ agarose gel using a Tris-borate buffer system (Maniatis et al. 1982). The size of the fragments was estimated by comparison with the migration of a $\lambda$-Hind III marker.

Re-infection tests. A small portion of the semipurified virus preparation from Urografin gradient centrifugation was diluted from 250 to $2.5 \times 10^{6}$ times (increments of $10 \times$ for a total of 5 dilutions, weight of sample by volume of buffer) in LHB. The diluted virus preparations were injected into groups of 10 prawns each maintained in $50 \mathrm{I}$ aquaria containing filtered, aerated sea water ( $15 \mathrm{ppt}$ ) at ambient temperature (approximately $30^{\circ} \mathrm{C}$ ). Prawns were observed for $8 \mathrm{~d}$ for signs of morbidity and for mortality. When found, moribund shrimp were removed and hemolymph was removed for virus purification as described above. After bleeding, some shrimp were fixed in Davidson's fixative and processed for normal histology as described by Bell \& Lightner (1988). From other shrimp specimens, gills and lymphoid organs were fixed in $4 \%$ paraformaldehyde plus $1 \%$ glutaraldehyde in $0.1 \mathrm{M}$ phosphate buffer at $\mathrm{pH} 7$. Processing methods for TEM have been previously described (Fegan et al. 1991). 


\section{RESULTS}

\section{Primary virus isolation}

In the primary virus isolation, it was expected that high quantities of YHV virions would be obtained.
Instead, negative staining revealed the presence of a previously undescribed virus (Fig. 1) that outnumbered the YHV virions by approximately 4 to 1 . For the new virus, intact virions were cylindrical to elliptical or obovate and measured $121 \pm 9 \mathrm{~nm}$ in width at the widest point and $276 \pm 26 \mathrm{~nm}$ in length $(n=34)$,
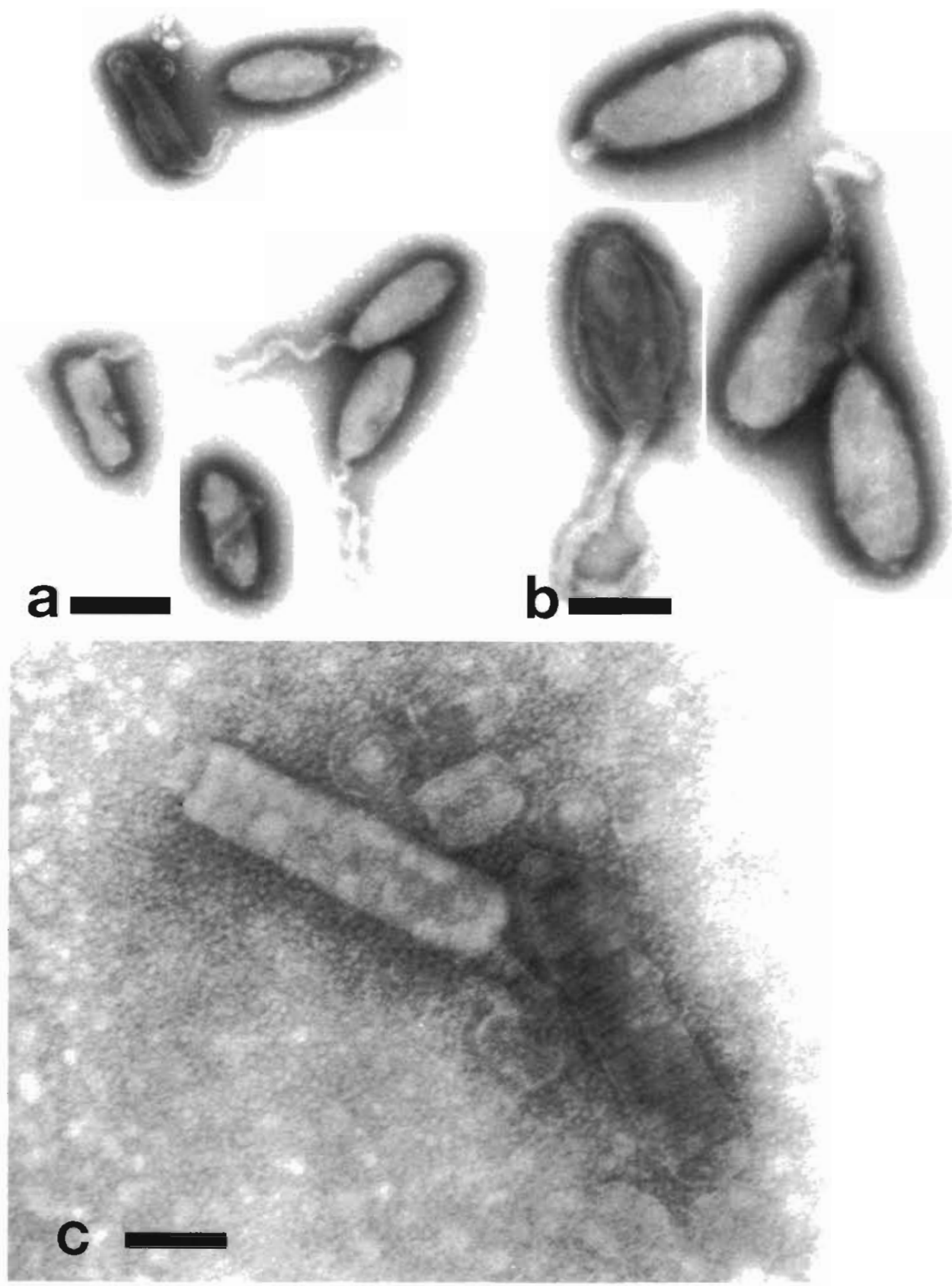

Fig. 1. Negatively stained virions purified by Urografin density centrifugation from hemolymph samples. (a) Low magnification of 5 fully enveloped virions showing multifibrillar appendages. The stain has penetrated 1 virion (upper left) which shows an appendage different from that of the intact virions but similar to that found in other baculoviruses. Scale bar $=240 \mathrm{~nm}$. ( $\mathrm{b}$ ) Higher magnification of 4 enveloped virions with multifibrillar appendages. Stain has penetrated the virion on the lower left, revealing the nucleocapsid. Scale bar $=150 \mathrm{~nm}$. (c) Unenveloped nucleocapsids. Stain has penetrated one to reveal a banding pattern perpendicular to its long axis. Scale bar $=100 \mathrm{~nm}$ 
excluding the multifilament appendage which was seen attached at the narrow end of many. Measurements for nucleocapsids for empty virions with intact envelopes were $89 \pm 7$ width by $201 \pm 18$ length $(n=8)$. However, measurements for nucleocapsids from virions with broken envelopes were width $73 \pm 17$ and length $302 \pm 17(n=3)$, indicating some extension upon rupture. These 'extended' nucleocapsids showed a pattern of electron-opaque bands (18 nm) alternating with electron-transparent bands $(3 \mathrm{~nm})$, arranged perpendicular to the long axis of the nucleocapsid.

\section{Re-infection tests}

At the lowest dilution of the semi-purified virus preparation $(1: 250)$, all 10 test prawns were moribund by Day 6 after injection. At the next highest dilution (1:2500), total morbidity was seen by Day 7 . At the succeeding higher dilutions morbidity was $40 \%$ and $20 \%$, respectively, by Day 8 . Moribund prawns were lethargic and had a pale coloration, but did not show a yellow discoloration of the cephalothorax as sometimes occurs with yellow-head infections.

\section{Histology with the light microscope}

Normal histology with hematoxylin and eosin staining of moribund animals showed some typical basophilic inclusions characteristic of yellow-head infections (Chantanachookin et al. 1993). However, in addition to these inclusions, there was hemocytic infiltration of the gills, hepatopancreatic hemal sinuses, and hemocoel and widespread focal necrosis in tissues of ectodermal and mesodermal origin. In mid stages of virus development, cellular pathology distinct from that reported for yellow-head (Fig 2) consisted of hypertrophied nuclei with eosinophilic inclusions and marginated basophilic chromatin, somewhat reminiscent of the Cowdry A inclusions characteristic for infections of IHHN virus (Lightner 1993). These were particularly evident in the epithelium of the stomach. In later stages of development, these inclusions were larger and their staining reaction changed from distinctly acidophilic to lightly basophilic. Also in these later stages, the transparent zone between the intranuclear inclusion and the marginated chromatin was no longer present. However, these inclusions were more widespread and more marked than the Cowdry A inclusions we have ever found with IHHNV infections in Penaeus monodon.

Thin sections of gill tissue stained with toluidine blue (Fig. 2d to h) showed hypertrophied nuclei with marginated chromatin set in enlarged epithelial cells. In early stages of infection, the cytoplasm was still visible, but it thinned as viral development progressed and was finally transparent, surrounding the nucleus. In later stages the nuclei also disintegrated, leaving enlarged vacant areas. Similar sections of the lymphoid organ from moribund shrimp ( $48 \mathrm{~h}$ or longer post-injection) showed massive necrosis, but this was not typical of YHV infection. The state of tissue disintegration was so extensive that no distinctive character could be attributed specifically to the new virus. In earlier stages of infection (i.e. $12 \mathrm{~h}$ post-injection) hypertrophied nuclei could be seen.

\section{Ultrastructure by the transmission electron microscope}

Examination of epithelial cells of the gills of reinfected prawns showed development of rod-shaped to elliptical, enveloped virions typical of the nonoccluded baculoviruses (Fig. 3). Completely assembled virions measured $292 \pm 29 \mathrm{~nm}(\mathrm{n}=11)$ by $111 \pm 8 \mathrm{~nm}$ $(\mathrm{n}=20)$ while capsids measured $244 \pm 28 \mathrm{~nm}(\mathrm{n}=11)$ by $80 \pm 11 \mathrm{~nm}(\mathrm{n}=20)$ and nucleic acid cores measured $204 \pm 28 \mathrm{~nm}(\mathrm{n}=11)$ by $66 \pm 11 \mathrm{~nm}(\mathrm{n}=20)$. When these measurements and those determined from negatively stained material (above) were compared (Table 1), some statistically significant differences were obtained. The negatively stained virions were shorter and fatter than those seen in the thin sections. Also, the width of unenveloped, empty nucleocapsids measured from tangential sections was $48 \pm 6 \mathrm{~nm}(\mathrm{n}=20)$, and this was significantly $(p<0.05)$ narrower than the capsid width $(80 \pm 11 \mathrm{~nm})$ for fully assembled virions. In the negatively stained material, the unenveloped capsid width was also significantly $(p<0.05)$ smaller than the enveloped width. Some virions cut in tangential section showed a nipple-like extension at one end, which probably corresponded to a portion of the filamentous extension seen in the negatively stained material described above. Also present in the sections were vacant capsids and envelopes. The envelope was clearly trilaminar, consisting of 2 electron-transparent layers divided by an electron-opaque layer, as is usual for baculoviruses (Adams \& McClintock 1991). In crosssection, the envelopes for complete virions varied from. round to somewhat pentagonal or hexagonal in shape.

In specimens prepared at $12 \mathrm{~h}$ post-injection of viral extract, signs of viral replication and complete virions were present in the nuclei of some cells of the lymphoid organ and in occasional hemocytes. Although there were signs of abnormal cytology in connective tissue of the hepatopancreas (e.g. hypertrophied nuclei), there was no clear evidence of viral replication there. The epithelial cells of the tubules showed no such abnormalities. 


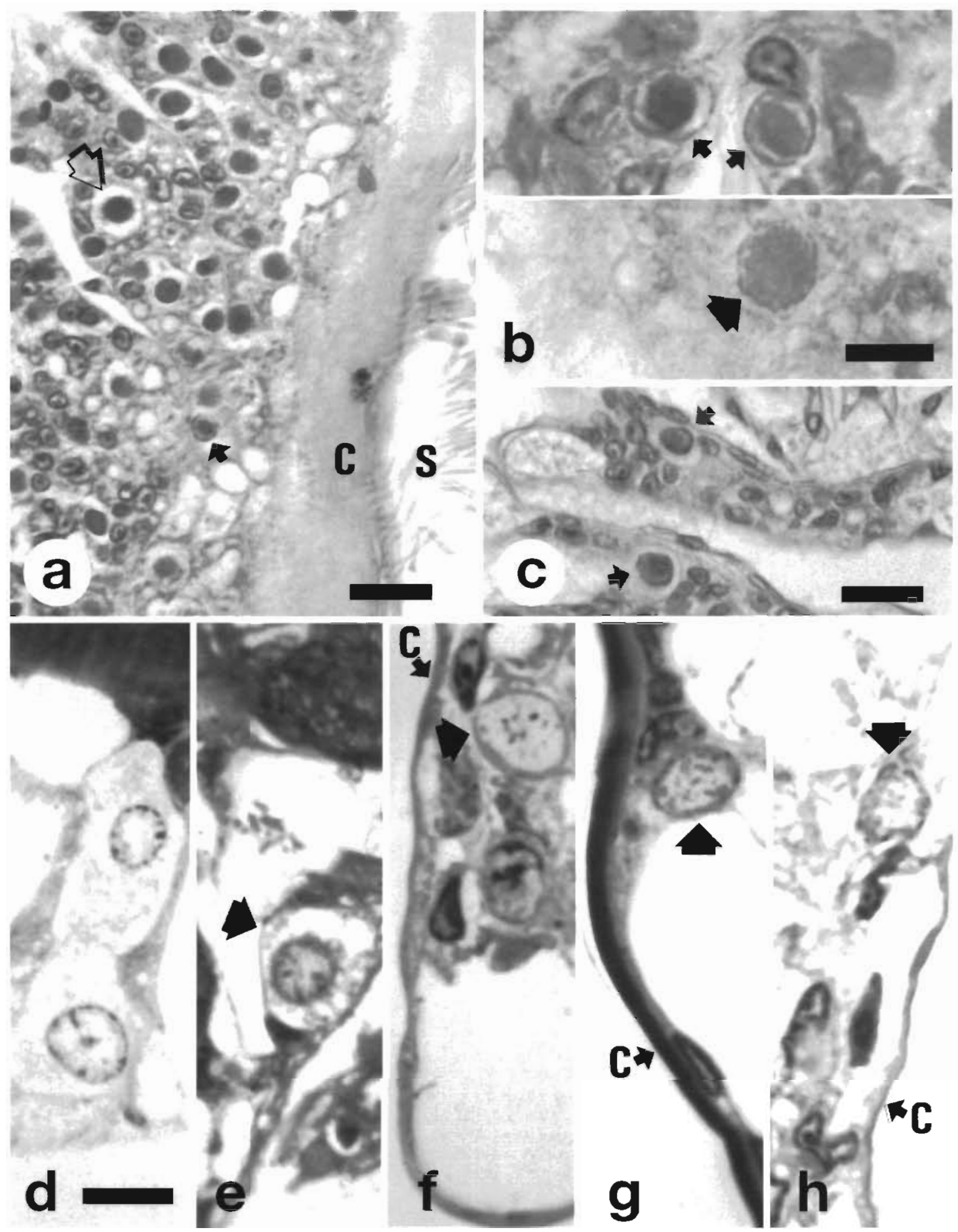

Fig. 2. Penaeus monodon. Histology by light microscope of tissues from shrimp injected with semi-purified virus from Urografin gradients. (a) Epithelial cells of the stomach showing pathology typical of this viral infection. Note the Cowdry A-type nuclear inclusion (small arrow) typical of early pathology. Other inclusions in the photograph are typical of later stages of pathological development, where the clear zone between the eosinophilic center and marginated chromatin is no longer present. These inclusions become more basophilic with age. Note the vacant cytoplasm surrounding the abnormal nuclei (large vacant arrow) and the completely vacant areas immediately underlying the cuticle. C: cuticle; S: stomach lumen. H\&E; scale bar $=15 \mu m$. (b) High magnification of early stage (small arrows) and late stage (large arrow) nuclear inclusions. H\&E; scale bar $=8 \mu \mathrm{m}$. (c) Low magnification of nuclei in the gills (arrows) showing eosinophilic inclusions and vacant surrounding cytoplasm. Scale bar $=15 \mu \mathrm{m}$. (d to h) High magnification of thin sections of infected gill tissue showing progressive stages in cellular pathology. C: cuticle. Toluidine blue. Scale bar $=8 \mu \mathrm{m}$ 


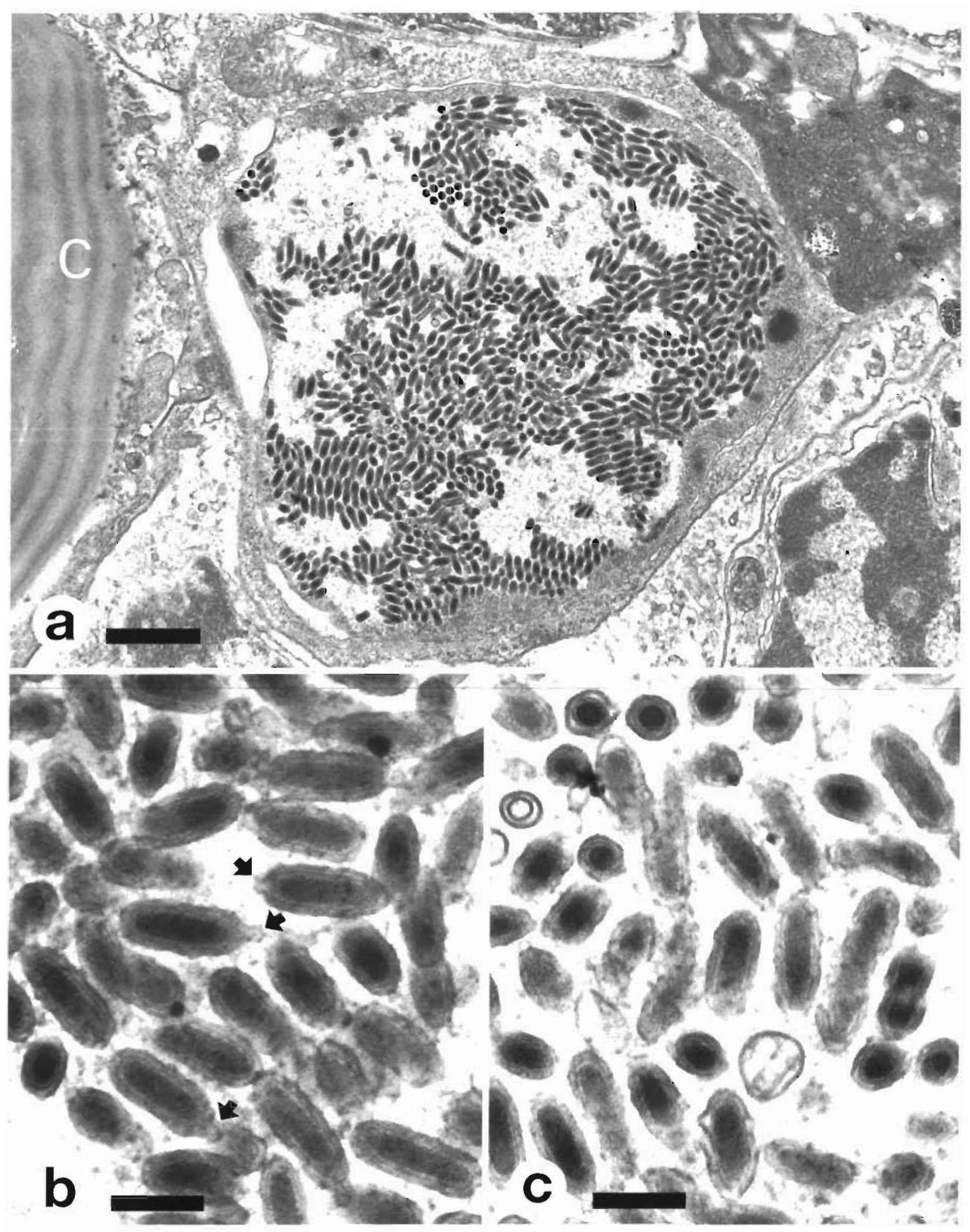

Fig 3. Penaeus monodon Transmission electron microscopy of thin-sectloned gill tissue from shrimp injected with semi-purified virus from Urografin gradients (a) Low magnification of an epithelial cell with a hypertrophied nucleus containing virions in vanous stages of assembly Scale bar $=2 \mu \mathrm{m}$ (b) Higher magnification of enveloped virions mostly in longitudinal section, some (arrows) showing an appendage at one end Scale bar $=200 \mathrm{~nm}$. (c) Enveloped virions, many in cross section, showing that the viral envelope is tral.amınar Scale bar $=200 \mathrm{~nm}$ 
Table 1. Comparıson of virion measurements from negatively staıned and thin-sectıoned material. -: unable to measure. Significant differences: " $p<0.05 ; " \mathrm{p}<0.01$

\begin{tabular}{|c|c|c|}
\hline \multirow[t]{2}{*}{ Portion of virion } & \multicolumn{2}{|c|}{ Mean virion measurement $(\mathrm{nm})$} \\
\hline & Negatively stained material & Thin-sectioned material \\
\hline Full virion (length) & 276 & 292 \\
\hline Full virion (width) ". & 121 & 111 \\
\hline Capsid in full virion (length) ${ }^{\prime}$ & 201 & 244 \\
\hline Capsid in full virion (width) & 89 & 80 \\
\hline Nucleic acid core in full virions (length) & - & 204 \\
\hline Nucleic acid core in full virions (width) & - & 66 \\
\hline Empty capsids w/o envelopes (length) & 302 & - \\
\hline Empty capsids w/o envelopes (width) ${ }^{\circ}$ & $73^{\mathrm{a}}$ & $48^{12}$ \\
\hline
\end{tabular}

\section{Nucleic acid isolation and characterization}

Agarose gel electrophoresis of nucleic acid isolated from the new virus (Fig. 4) showed that it was cut with 2 different restriction enzymes specific for doublestranded DNA. The average size of the viral genome, estimated from DNA fragments in this gel, was approximately 168 kilo base pairs. Preliminary dot-blot assays

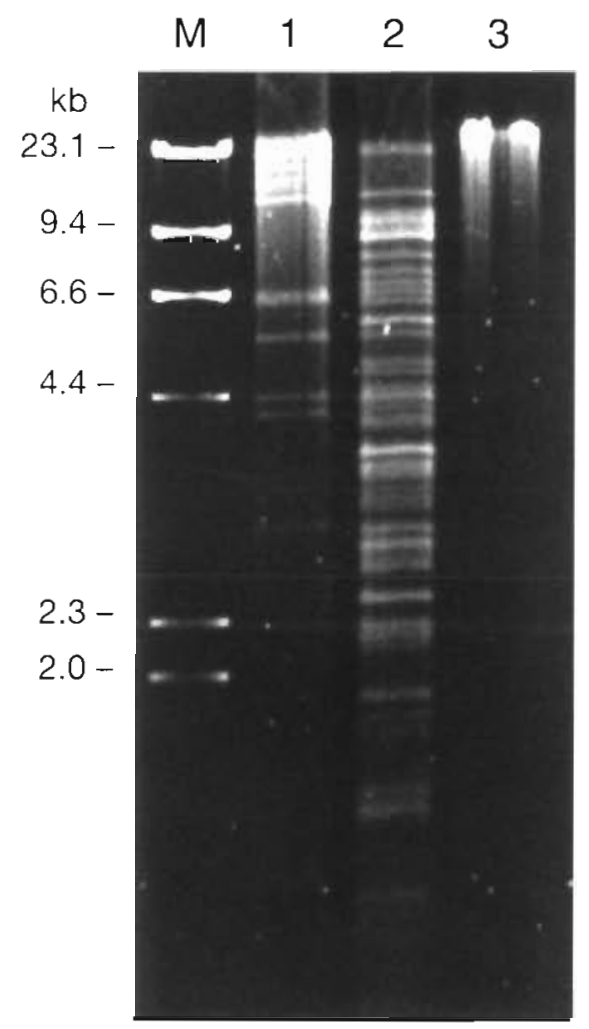

Fig. 4. Agarose gel $(0.8 \%)$ electrophoresis of viral DNA. Lanes: $M, \lambda$-Hind III marker; 1, EcoRI digestion products;

2, BamHI digestion products; 3 , undigested viral DNA with this DNA showed that it did not hybridize with DNA fragments from MBV or with DNA isolated from YHV-infected shrimp.

\section{DISCUSSION}

This new baculovirus is the third systemic baculovirus described for penaeid shrimp and it differs significantly from those previously described (Boonyaratpalin et al. 1993, Chantanachookin et al. 1993, Owens 1993). Virions of the hemolymph baculovirus described by Owens (1993) were much larger (ordinary length 430 to $640 \mathrm{~nm}$ ), they were sometimes bent or folded, and they were located in membrane-bound vacuoles or free in the cytoplasm of hemocytes. The other systemic baculovirus, YHV (Boonyaratpalin et al. 1993, Chantanachookin et al. 1993), is assembled predominantly in the cytoplasm and mature virions in thin sections are about half the size $(173 \times 44 \mathrm{~nm})$ of those reported here for the new virus $(292 \times 111 \mathrm{~nm})$. Because it infects cells of ectodermal and mesodermal origin (e.g. subcuticular epithelial cells, the lymphoid organ, hemocytes), we call this virus 'Systemic Ectodermal and Mesodermal Baculovirus' (SEMBV). As with other baculoviruses, this virus produces hypertrophied nuclei that have eosinophilic inclusions (H\&E staining) and marginated chromatin. However, the inclusions differ in early development since they are surrounded by a clear zone (in Davidson's fixed tissue) and appear similar to the Cowdry A-type inclusions seen with infections of IHHNV. Unlike IHHNV, though, the inclusions change from eosinophilic to basophilic with age and the nucleus is surrounded by vacant cytoplasm. These features can be used to distinguish infections caused by SEMBV from those caused by YHV (which produces basophilic cytoplasmic inclusions) and IHHNV (which produces unchanging eosinophilic 
nuclear inclusions without vacant cytoplasm). The histological profile of intranuclear eosinophilic inclusions without polyhedrin is similar to that reported for nonoccluded baculovirus infections in penaeid shrimp (Lightner 1993).

The size of mature SEMBV virions is similar to that of monodon baculovirus (MBV). However, for several reasons SEMBV is distinct from MBV. First of all, MBV has never been reported by normal histology from ather than tissues of the hepatopancreas and midgut (Lightner 1993) and recent results with in situ DNA hybridization studies have confirmed this tissue restriction (Lightner et al. 1994). In addition, the lack of intranuclear occlusion bodies, and the obovate, appendaged appearance of negatively stained virions of SEMBV are strikingly different features from MBV. Further evidence for the distinctiveness of SEMBV comes from our inability to obtain cross-hybridizations between DNA from the 2 viruses (authors' unpubl. data).

Based on the morphology, size, site of assembly, cellular pathology and nucleic acid content, SEMBV should be placed in group $\mathrm{C}$ (Type $\mathrm{C}$ ) of the family Baculoviridae (Huger \& Krieg 1991). Lightner (1993) reports that 2 Type $\mathrm{C}$ baculoviruses have so far been recognized in penaeid shrimp. Neither of these cause systemic infections as both are confined to the hepatopancreas or midgut tissues. One of these viruses occurs in Penaeus monodon, but is not well characterized. The other occurs in $P$. japonicus and has been better characterized. It is called baculoviral. midgut gland necrosis virus or BMN virus. The average size of enveloped virions of $B M N$ is $72 \times 310 \mathrm{~nm}$, and this is close to the size for MBV and SEMBV. However, BMN resembles MBV and differs from SEMBV in terms of viral morphology and restriction to the hepatopancreas. The Type $\mathrm{C}$ baculoviruses are now included in the subfamily Nudibaculovirinae (Francki et al. 1993) where SEMBV would be formally named PmNOBII, as the second non-occluded baculovirus reported for P. monodon

The fact that negatively stained virions isolated from the hemolymph measured shorter and thicker than virions measured from thin-sectioned material could be real or could be an artifact resulting from differences in specimen preparation. However, the smaller width of the unenveloped capsids versus enveloped capsids was unlikely to be an artifact because significant differences were found between the 2 within the negatively stained and thin-section groups (Table 1). Thus, it seems that the nucleocapsid shortens and thickens upon acquisition of its nucleic acid core.

The nudibaculoviruses reported for crabs (Huger \& Krieg 1991) show some superficial resemblance to SEMBV in terms of size, cytopathology, and lack of restriction to the hepatopancreas and mid-gut. However, detailed examination of transmission electron micrographs shows that virions of the crab viruses resemble those of $\mathrm{MBV}$ and BMN more closely than they do SEMBV Specifically, in negatively stained material, SEMBV shows a distinctive multifibrillar appendage greater in length than the virion itself, and this appendage appears to be a normal attachment or extension of the mature viral envelope. By contrast, the appendages reported for MBV (Flegel et al. 1992, Mari et al. 1993) and for the crab baculoviruses (Huger \& Krieg 1991) are shorter, not multifibrillar, and appear to be folded inside the viral envelope until it ruptures. In addition, the banding pattern for protein subunits in the nucleocapsids for MBV and the crab baculoviruses is offset at an angle to the long axis of the capsid and not perpendicular to it as in SEMBV.

It is difficult to guess the source of SEMBV. It was curious that the rapid mortality that resulted upon injection of the semi-purified preparation of SEMBV was similar to that reported for YHV (Boonyaratpalin et al. 1993, Chantanachookin et al. 1993). The fact that the development of the primary infection was accidental and arose during an attempted YHV transmission trial suggested that there might be some relationship between the 2 viruses and the reported outbreaks of yellow-head syndrome. It is possible that SEMBV was overlooked in the original investigations on yellowhead syndrome. However, the authors feel that this is unlikely. In the interval 1992 to 1993, they examined gill tissues of over 60 specimens of YHV-infected prawns from natural outbreaks with the transmission electron microscope and never saw any non-occluded baculovirus particles in subcuticular epithelial cells. By contrast, YHV virions were present in massive quantities in the same cells (Chantanachookin et al. 1993). It is possible that SEMBV was present, but in such low quantities that it was not found.

Work on transmission and characterization of YHV has been carried out with virus preparations serially transferred in research facilities over many passages without purification steps other than membrane filtration Boonyaratpalin et al. 1993, Kasornchandra et al. 1993). If SEMBV was present in very low quantities in some of the original isolates of YHV used in the serial transmission experiments, it is possible that SEMBV was somehow preferentially amplified during the transmission process. In support of this proposal are results from a time-course laboratory study of acute induced YHV infections in Penaeus monodon reported by Kasornchandra et al. (1993). This study showed that the first signs of YHV replication in the lymphoid organ occurred as nuclear assembly of non-occluded baculovirus particles later than $18 \mathrm{~h}$ post-injection. In a similar, preliminary time-lapse study with SEMBV, 
the first signs of pathology occurred $6 \mathrm{~h}$ post-injection (authors' unpubl. data). If the development of SEMBV is more rapid than YHV in Penaeus monodon, then multiple serial transfers of a mixed virus sample beginning with a small quantity of SEMBV relative to YHV could easily lead to increasing quantities of SEMBV in succeeding groups of experimental animals.

Even if this hypothesis for SEMBV amplification is correct, we are still left with the question of the relationship between SEMBV and YHV in causing yellowhead mortality. However, the massive quantity of virions present in the natural YHV infections and the related tissue necrosis suggest that YHV was the cause of death in the yellow-head outbreaks. Similarly, the massive quantity of SEMBV virions and the associated cellular damage suggest that the mortality in the reinfection trials was caused primarily by SEMBV. This would, in turn, suggest that SEMBV, like YHV, is an extremely virulent pathogen for Penaeus monodon.

In any case, more detailed studies are needed to determine whether these viruses work synergistically in causing yellow-head mortality. One possible way to answer this question would be to carry out in situ DNA hybridization tests for dual infections with tissue preparations from past yellow-head outbreaks. Specific DNA probes for these viruses should soon be available. In addition, appropriate primers based on such probes will make it possible to screen purified viral preparations and test animals for the presence of even traces of contaminating virus by the PCR technique. In this manner, it should be possible to isolate the effects of the 2 viruses and to carry out dual infection studies, even without standardized test animals. If Penaeus vannamei is susceptible to YHV or SEMBV or both, it would be useful to carry out these infection studies with specific pathogen-free (SPF) stocks that are now available (Wyban 1992). This could be done after they had been tested for the presence of YHV and SEMBV-DNA by the PCR technique.

Acknowledgements. The authors thank the National Center for Genetic Engineering and Biotechnology for grant funding to support this research and Aquastar Co. Ltd for support in bringing Dr Vickers to Thailand.

\section{LITERATURE CITED}

Adams JR, McClintock JT (1991) Baculoviridae. Nuclear polyhedrosis viruses. Part I. Nuclear polyhedrosis viruses of insects. In: Adams JR, Bonami JR (eds) Atlas of invertebrate viruses. CRC Press, Boca Raton, p 87-204

Anonymous (1993) Asian Shrimp News, 2nd Quarter, No 14, Bangkok

Responsible Subject Editor: J. E. Stewart, Dartmouth, Nova Scotia, Canada
Bell TA, Lightner DV (1988) A handbook of normal penaeid shrimp histology. World Aquaculture Society, Baton Rouge

Boonyaratpalin S, Supamataya K, Kasornchandra J, Direkbusarakom $\mathrm{S}$, Ekpanithanpong U, Chantanachookin $\mathrm{C}$ (1993) Non-occluded baculo-like virus the causative agent of yellow-head disease in the black tiger shrimp Penaeus monodon. Gyobo Kenkyu (Fish Pathol) 28:103-109

Chantanachookin C, Boonyaratpalin S, Kasornchandra J, Direkbusarakom S, Ekpanithanpong [], Supamataya K, Sriurairatana S, Flegel TW (1993) Histulogy and ultrastructure reveal a new granulosis-like virus in Penaeus monodon affected by yellow-head disease. Dis aquat Org 17:145-157

Fegan DF, Flegel TW, Sriurairatana S, Waiyakruttha M (1991) The occurrence, development and histopathology of monodon baculovirus in Penaeus monodon in southern Thailand. Aquaculture 96:205-217

Flegel TW, Fegan DF, Kongsom S, Vuthikornudomkit S, Sriurairatana $\mathrm{S}$, Boonyaratpalin $\mathrm{S}$, Chantanachookhin C, Vickers JE, Macdonald OD (1992) Occurrence, diagnosis and treatment of shrimp diseases in Thailand. In: Fulks W, Main KL (eds) Diseases of cultured penaeid shrimp in Asia and the United States. Oceanic Institute, Honolulu, $p$ $57-112$

Francki RIB, Fauquet, CM, Knudson DL, Brown F (eds) (1991) Classification and nomenclature of viruses, 5th report of the International Committee on Taxonomy of Viruses. Springer-Verlag, New York

Huger AM, Krieg A (1991) Baculoviridae. Nonoccluded baculoviruses. In: Adams JR, Bonami JR (eds) Atlas of invertebrate viruses. CRC Press, Boca Raton, p 287-319

Kasornchandra J. Supamattaya K, Boonyaratpalin S (1993) Electron microscopic observations on the replication of yellow-head baculovirus in the lymphoid organ of Penaeus monodon. Asian Shrimp News, 3rd Quarter, No 15, Bangkok, p 2-3

Lightner DV (1993). Diseases of cultured penaeid shrimp. In: McVey JP (ed) CRC handbook of mariculture, 2nd edn, Vol 1. Crustacean aquaculture. CRC Press, Boca Raton, p 393-486

Lightner DV, Poulos BT, Bruce L, Redman RM, Nunan L, Pantoja C, Marı J. Bonami JR (1994) The use of genomic probes in in situ hybridization assays as diagnostic and research reagents for the penaeid shrimp parvoviruses, IHHNV and HPV, and the baculoviruses MBV and PB. In: Proc Conference on Marine Biotechnology in the Asian Pacific Region, 16-20 Nov. 1993, Bangkok. World Bank, Washington, DC (in press)

Maniatis T, Fritsch EF, Sambrook J (1982) Molecular cloning. A laboratory manual. Cold Spring Harbor Laboratory, Cold Spring Harbor, NY

Mari J, Bonami J-R, Poulos B, Lightner DV (1993) Prehmınary characterization partial cloning of the genome of a baculovirus from Penaeus monodon (PmSNPV $=\mathrm{MBV})$. Dis aquat Org 16:207-215

Owens L (1993) Description of the first haemocytic rodshaped virus from a penaeid prawn. Dis aquat Org 16:217-221

Wyban JA (1992) Selective breeding of specific pathogen free (SPF) shrimp for high health and increased growth. In: Fulks W, Main KL (eds) Diseases of cultured penaeid shrimp in Asia and the United States. Oceanic Institute, Honolulu, p 257-268

Manuscript first received: May 25, 1994

Revised version accepted: August 22, 1994 